\title{
Bitki Artıkları ve Yeşil Gübrelemenin Makarnalık Buğday Verim ve Kalite Özelliklerine Etkisi
}

\author{
*Erol KARAKURT ${ }^{1}$ Asuman KAPLAN EVLICE ${ }^{1}$ Aliye PEHLIVAN ${ }^{1}$ Derya SÜREK ${ }^{2}$
}

\author{
${ }^{1}$ Tarla Bitkileri Merkez Araştırma Enstitüsü Müdürlüğü, Ankara \\ ${ }^{2}$ Toprak Gübre ve Su Kaynakları Merkez Araştırma Enstitüsü Müdürlüğü, Ankara \\ *Sorumlu yazar e-posta (Corresponding author; e-mail): erol_karakurt@hotmail.com
}

\begin{abstract}
Öz
Kıraç şartlarda ve çakılı olarak 2003-2004 ve 2004-2005 yetiştirme yıllarında yürütülen denemede; yeşil gübreleme ve nadas uygulamalarının makarnalık buğdayın verim ve kalitesi üzerindeki etkisi araştırıımıştır. Denemede; tüylü fiğ, tritikale, aspir, anız+sap ilavesi, fiğ+tritikale karışımı, kışıık mercimek, yaygın fiğ, yazlık mercimek, geleneksel nadas (Mart sonu) ve geç nadas (Haziran sonu) olmak üzere on farklı uygulama sonrası makarnalık buğday, gübreli ( $6 \mathrm{~kg} \mathrm{~N} / \mathrm{da})$ ve gübresiz $(0 \mathrm{~kg} \mathrm{~N} / \mathrm{da})$ olarak yetiştirilmiştir. Çalışma sonucunda, özellikle tüylü fiğ sonrası makarnalık buğday yetiştirilmesinde daha iyi sonuçlar alınmış, bu uygulamayı yaygın fiğ ve geleneksel nadas takip etmiştir. En düşük değerler ise tritikale ve kışlık mercimek sonrası ekilen buğdaylardan elde edilmiştir. Ayrıca, $6 \mathrm{~kg} \mathrm{~N} / \mathrm{da}$ gübre uygulaması ile irmik verimi hariç diğer bütün verim ve kalite özelliklerinde daha yüksek değerler elde edilmiştir.
\end{abstract}

Anahtar Kelimeler: Yeşil gübreleme, organik madde, makarnalık buğday, verim, kalite

\section{Effect of Crop Residues and Green Manures on Yield and Quality Characteristics of Durum Wheat}

\begin{abstract}
The trial was conducted in arid conditions during 2003-2004 and 2004-2005 growing seasons to investigate the effect of green manure and fallow treatments on the yield and quality of durum wheat. Durum wheat was sown with fertilized ( $6 \mathrm{~kg} \mathrm{~N} / \mathrm{da}$ ) and non-fertilized $(0 \mathrm{~kg} \mathrm{~N} / \mathrm{da})$ after ten different treatments which are hairy vetch, triticale, safflower, stubble+stalk addition, vetch+triticale mixture, winter lentil, common vetch, summer lentil, traditional fallow (late March) and late fallow (late June). As a result, durum wheat grown especially after hairy vetch was showed better results, followed by common vetch and traditional fallow while the lowest results were obtained from durum wheat sown after triticale and winter lentil. In addition, higher values were obtained with $6 \mathrm{~kg} \mathrm{~N} / \mathrm{da}$ fertilizing at all yield and quality parameters except semolina yield.
\end{abstract}

Keywords: Green manuring, organic matter, durum wheat, yield, quality

\section{Giriş}

-oprakların verimliliklerinin artırılması ve devamlılığının sağlanması ancak toprağa ilave olunan organik kökenli gübrelerle mümkündür. Toprak verimliliğinin organik madde, organik maddenin ise yeşil gübreleme ile sıkı bir bağlantısı bulunmaktadır (Zabunoğlu ve Karaçal 1986; Açıkgöz 2001). Farklı yeşil gübre bitkilerinin yazlık tahıl verimine etkilerinin araştırıldığı bir çalışmada, kontrole göre yazlık buğdayda 13-170 kg/da, yazlık arpada ise 25$100 \mathrm{~kg} / \mathrm{da}$ verim artışı sağlanmıştır (Kahnt 1983). Kanada koşullarında mercimek (erkengeç dönemde), mercimek (tane için), bezelye, buğday (azot gübreleme-gübresiz) ve nadas sonrası 7 farklı yeşil gübre uygulamasının, buğday verimine etkisinin araştırdığı denemede; $210.5 \mathrm{~kg} / \mathrm{da}$ ile en yüksek buğday verimi, mercimek (erken dönemde) yeşil gübreleme uygulamasından, en düşük verim (143.6 kg/da) ise buğday (gübresiz) yeşil gübre uygulamasından elde edilmiştir (Brandt 1996).

Yeşil gübreleme ile önemli bir miktar azot toprağa uygulanmış olur. Normal gübrelemeden farklı olarak, organik maddenin uzun sürede ayrışması ile azot toprağa yavaş yavaş salınır, bu da yıkanma ile kayıpların önüne geçer ve geç dönemde bitkinin ihtiyacı olan azotu sağlar. Geç dönemde uygulanan azot, buğdayda protein miktarını arttırmaktadır (Talgre et al. 2009). 
Buğdayda kalite parametreleri önemli ölçüde protein miktarından, protein miktarı da genotip ve yetiştirilme koşullarından etkilenmektedir (Atlı 1999).

Bu çalışmada; organik madde içeriği düşük olan Orta Anadolu Bölgesi (\%1.7) koşullarında (Anonim 1996) nadas-buğday ekim nöbeti sisteminde nadasın yerine geçebilecek uygun bir yeşil gübre bitkisinin tespiti ile yeşil gübre bitkilerinin toprağa ilavesinden sonra gübreli ve gübresiz koşullarda yetiştirilen makarnalık buğdayda verim ve kalite özelliklerinin ortaya konması amaçlanmıştır.

\section{Materyal ve Yöntem}

Deneme; Tarla Bitkileri Merkez Araştırma Enstitüsü'ne ait Haymana/ikizce Araştırma ve Uygulama Çiftliği tarlasında, tesadüf bloklarında bölünmüş parseller deneme deseninde, 3 tekerrürlü ve kıraç şartlarda çakılı olarak, 20032004 ve 2004-2005 yetiştirme dönemlerinde yürütülmüştür.

Denemede; tüylü fiğ, yaygın fiğ, tritikale, aspir, kışlık mercimek, yazlık mercimek, anız+sap ilavesi, fiğ+tritikale karışımı, geleneksel nadas (Mart ayı) ve geç nadas (Haziran sonu) olmak üzere 10 farklı uygulama yer almıştır. En küçük parsel $5 \mathrm{~m} \times 15 \mathrm{~m}=75 \mathrm{~m}^{2}$ dir. Ekim normu olarak; tüylü fiğ, yaygın fiğ, tritikale, kışlık mercimek ve yazlık mercimek için 12-14 kg/da, aspir için $2 \mathrm{~kg} / \mathrm{da}$, fiğ+tritikale karışımı için $11+4 \mathrm{~kg} / \mathrm{da}$ ve makarnalık buğday için $22 \mathrm{~kg} / \mathrm{da}$ tohum miktarı kullanılmıştır. Çalışmada protein kalitesi ve sarılık değeri yüksek Altın 40/98 makarnalık buğday çeşidi kullanılmıştır. Denemede; ana parseller yeşil gübre bitkileri ve nadas uygulamalarını, alt parselleri ise gübre uygulamalarını (G-=gübresiz: $0 \mathrm{~kg} \mathrm{~N} / \mathrm{da}$ ve $\mathrm{G}+=$ =gübreli: $6 \mathrm{~kg}$ $\mathrm{N} / \mathrm{da}$ ) oluşturmaktadır.

Makarnalık buğdayda; bitki boyu, $\mathrm{m}^{2}$ deki başaklı bitki sayısı, başak ağırlığı, başakta tane sayısı, başakta tane ağırığı ve tane verimi gibi tarımsal özellikler (Kurt ve Tan, 1984; Açıkgöz 2001) ile hektolitre ağırlığı, bin tane ağırlığı, b sarılık değeri, sedimantasyon testi, irmik verimi ve protein gibi bazı kalite (Vasiljevic and Banasik 1980; Williams et al.1988; Köksel ve ark. 2000; Anonymous 2002) parametreleri incelenmiştir.

Deneme sonuçlarının istatistiksel olarak değerlendirilmesi Yurtsever (1984)'ten yararlanılarak yapılmıştır. Varyans analizinde ve önemlilik testlerinde farklı grupların belirlenmesinde MSTAT-C paket programı kullanılmıştır (Anonymous 1990).

\section{Bulgular ve Tartışma \\ Toprağa Gömülen Kuru Madde Miktarı}

Farklı yeşil gübre bitkileri ve nadas uygulamaları sonrası toprağa gömülen kuru madde miktarı Çizelge 1 'de verilmiştir.

Çizelgede 1 'de görüldüğü üzere, toprağa gömülen kuru madde miktarı yönünden; 2004 ve 2005 yıllarında ve birleşik analiz sonucunda, uygulamalar arasındaki fark istatistiki olarak önemli bulunmuştur $(p<0.01)$. Toprağa gömülen kuru madde miktarı; 2004 yılında en yüksek tritikale $(210.5 \mathrm{~kg} / \mathrm{da}), 2005$ yılında ise sap+anız ilavesi, tüylü fiğ+tritikale karışımı, tüylü fiğ, aspir, tritikale ve kışlık mercimek uygulamalarından sırasıyla 229.2, 227.0, 217.7, 214.8, 212.4 ve $194.7 \mathrm{~kg} / \mathrm{da}$ elde edilmiştir. Íki yılın ortalama değerleri yönünden toprağa gömülen kuru madde miktarı en yüksek tritikale $(211.4 \mathrm{~kg} / \mathrm{da})$, tüylü fiğ+tritikale karışımı (202.0 kg/da), tüylü fiğ (191.8 $\mathrm{kg} / \mathrm{da})$, aspir (190.2 kg/da) ve sap+anız ilavesi (185.5 kg/ha) uygulamalarından elde edilmiştir.

\section{Makarnalık Buğdayda İncelenen Bazı Agronomik Özellikler}

Yeşil gübre bitkileri ve nadas uygulaması sonrası ekilen makarnalık buğdayda tek başak ağırlığı, başaktaki tane sayısı ve başaktaki tane ağırlığı değerleri Çizelge 2'de, metre karedeki başak sayısı, bitki boyu ve tane verimi değerleri ise Çizelge 3'te verilmiştir. Ana parsel ortalama değerleri yönünden, uygulamalar arası farklılık sadece tane verimi ve başak sayısında istatistiki olarak önemli $(p<0.01)$ bulunmuştur. Alt parsel ortalama değerleri yönünden, incelenen agronomik özelliklerin tümünde uygulamalar arasındaki fark istatistiki olarak önemli çıkarken, ana parsel $x$ alt parsel interaksiyonu yönünden ise incelenen tarımsal özelliklerin hiç birinde farklılık önemli bulunmamıştır (Çizelge 2, 3). Gübreli ve gübresiz uygulamalar (alt parsel) açısından tek başak ağırlığı, başaktaki tane sayısı ve başaktaki tane ağırlığı yönünden incelendiğinde, aradaki fark istatistiki olarak önemli bulunmuş ve gübreli uygulamalardan daha yüksek değer edilmiştir. Ana parsel değerleri ile Ana parsel $x$ alt parsel interaksiyonu ise istatistiki olarak önemsiz bulunmuştur. Başaktaki tane sayısı ve tane ağırığı değerleri incelendiğinde, gübreli ve gübresiz koşulların yer aldığı alt parsel uygulamalarında ortalamalar arasındaki fark istatistiki olarak $\% 5$ düzeyinde önemli bulunmuştur. Makarnalık buğdayda ele alınan her iki özellik yönünden gübreli uygulamalardan elde edilen değerler, gübresiz uygulamalara göre daha yüksek olmuştur (Çizelge 2). 
Çizelge 1. Yeşil gübre bitkileri ve nadas uygulamaları sonrası toprağa gömülen kuru madde miktarı Table 1. Amount of dry matter buried after green manure and fallow applications

\begin{tabular}{|c|c|c|c|}
\hline \multirow{2}{*}{$\begin{array}{l}\text { Yeşil gübre bitkileri ve } \\
\text { Nadas uygulamaları }\end{array}$} & \multicolumn{3}{|c|}{ Toprağa gömülen kuru madde miktarı (kg/da) } \\
\hline & 2004 & 2005 & Ortalama \\
\hline Tüylü fiğ & $165,9 c$ & $217.7 a$ & $191.8 \mathrm{ab}$ \\
\hline Tritikale & $210.5 a$ & $212.4 a$ & $211.4 a$ \\
\hline Aspir & $165.5 \mathrm{c}$ & $214.8 a$ & 190.2ab \\
\hline Geleneksel nadas & $50.1 \mathrm{e}$ & $68.5 e$ & $59.3 e$ \\
\hline Geç nadas & 77.0de & $82.4 \mathrm{de}$ & 79.7de \\
\hline Anız+sap ilavesi & $141.7 \mathrm{bc}$ & $229.2 a$ & $185.5 a b$ \\
\hline Tüylü fiğ + tritikale karışımı & $177.0 \mathrm{bc}$ & $227.0 a$ & $202.0 a$ \\
\hline Kışlık mercimek & $119.2 d$ & 194.7ab & $156.8 \mathrm{~b}$ \\
\hline Yazlık mercimek & $95.9 d$ & $138.8 \mathrm{bcd}$ & $117.3 c$ \\
\hline Yaygın fiğ & $118.2 d$ & $106.2 \mathrm{cde}$ & $112.2 \mathrm{~cd}$ \\
\hline Ortalama & 128.3 & 169.2 & 150.6 \\
\hline $\mathrm{F}_{(\text {ana parsel) }}$ & ** & $* *$ & $* *$ \\
\hline $\mathrm{AOOF}_{(0.05) \text { (ana parsel) }}$ & 44.44 & 58.30 & 35.38 \\
\hline $\mathrm{DK}_{(\%)}$ & 18.39 & 21.19 & 20.06 \\
\hline
\end{tabular}

$\mathrm{F}:{ }^{*} 0.05$ düzeyinde önemli, ** 0.01 düzeyinde önemli

F: * significant at 0.05 level, ** significant at 0.01 level

Çizelge 2. Makarnalık buğdayda tek başak ağırlığı, başaktaki tane sayısı ve başaktaki tane ağırığı değerleri Table 2. Spike weight, kernel number per spike and kernel weight per spike values of durum wheat

\begin{tabular}{|c|c|c|c|c|c|c|c|c|c|}
\hline \multirow{3}{*}{$\begin{array}{l}\text { Yeşil gübre bitkileri ve } \\
\text { nadas uygulamaları }\end{array}$} & \multicolumn{3}{|c|}{$\begin{array}{l}\text { Başak ağırlığı } \\
\text { (adet/g) }\end{array}$} & \multicolumn{3}{|c|}{$\begin{array}{l}\text { Başaktaki tane sayısı } \\
\text { (adet/basak) }\end{array}$} & \multicolumn{3}{|c|}{$\begin{array}{c}\text { Başaktaki tane ağırlığı } \\
\text { (g/başak) }\end{array}$} \\
\hline & \multirow[t]{2}{*}{$\begin{array}{l}\text { Ana } \\
\text { Parsel }\end{array}$} & \multicolumn{2}{|c|}{$\begin{array}{l}\text { Ana x Alt } \\
\text { Parsel İnt, }\end{array}$} & \multirow[t]{2}{*}{$\begin{array}{l}\text { Ana } \\
\text { Parsel }\end{array}$} & \multicolumn{2}{|c|}{$\begin{array}{l}\text { Ana } \times \text { Alt } \\
\text { Parsel İnt, }\end{array}$} & \multirow[t]{2}{*}{$\begin{array}{l}\text { Ana } \\
\text { Parsel }\end{array}$} & \multicolumn{2}{|c|}{$\begin{array}{l}\text { Ana } \times \text { Alt } \\
\text { Parsel İnt, }\end{array}$} \\
\hline & & $\mathrm{G}+$ & G- & & $\mathrm{G}+$ & G- & & $\mathrm{G}+$ & G- \\
\hline Tüylü fiğ & 2.25 & 2.30 & 2.20 & 37.0 & 37.7 & 36.4 & 1.53 & 1.57 & 1.50 \\
\hline Tritikale & 2.13 & 2.03 & 2.23 & 33.4 & 32.8 & 34.1 & 1.45 & 1.37 & 1.53 \\
\hline Aspir & 2.03 & 2.13 & 1.93 & 32.0 & 33.8 & 30.2 & 1.42 & 1.47 & 1.37 \\
\hline Geleneksel nadas & 2.13 & 2.03 & 2.23 & 33.2 & 32.2 & 34.2 & 1.45 & 1.40 & 1.50 \\
\hline Geç nadas & 1.98 & 2.00 & 1.97 & 31.4 & 32.0 & 30.8 & 1.32 & 1.30 & 1.33 \\
\hline Anız+sap ilavesi & 1.90 & 2.00 & 1.80 & 29.7 & 32.3 & 27.1 & 1.30 & 1.37 & 1.23 \\
\hline T.fiğ+tritikale karışımı & 2.15 & 2.27 & 2.03 & 34.9 & 37.9 & 31.8 & 1.47 & 1.57 & 1.37 \\
\hline Kışlık mercimek & 2.05 & 2.20 & 1.90 & 34.0 & 36.0 & 32.0 & 1.37 & 1.50 & 1.23 \\
\hline Yazlık mercimek & 2.00 & 2.20 & 1.80 & 33.2 & 36.4 & 30.0 & 1.38 & 1.50 & 1.27 \\
\hline Yaygın fiğ & 2.17 & 2.30 & 2.03 & 35.6 & 38.0 & 33.3 & 1.47 & 1.53 & 1.40 \\
\hline Ortalama & 2.08 & $2.15 \mathrm{~A}$ & $2.01 \mathrm{~B}$ & 33.4 & $34.9 \mathrm{~A}$ & $32.0 \mathrm{~B}$ & 1.42 & $1.46 \mathrm{~A}$ & $1.37 \mathrm{~B}$ \\
\hline $\mathrm{F}_{\text {(alt parsel) }}$ & * & & & * & & & * & & \\
\hline $\mathrm{F}_{(\text {(ana parsel) }}$ & öd. & & & öd. & & & öd. & & \\
\hline$F_{\text {(alt } x \text { ana parsel int.) }}$ & öd. & & & öd. & & & öd. & & \\
\hline $\mathrm{AÖF}_{(0.05)(\text { alt parsel) }}$ & 0.10 & & & 1.56 & & & 0.08 & & \\
\hline $\mathrm{AÖF}_{(0.05)(\text { ana arsel) }}$ & - & & & - & & & - & & \\
\hline AÖF (0.05)(alt x ana parsel int) & _ & & & _ & & & - & & \\
\hline $\mathrm{DK}_{(\%)}$ & 9.06 & & & 8.63 & & & 10.40 & & \\
\hline
\end{tabular}

F: * 0.05 düzeyinde önemli, ** 0.01 düzeyinde önemli, öd.) önemli değil, gübre uygulaması G+:var, G-:yok

$F^{*}$ significant at 0.05 level, ** significant at 0.01 level, öd.) non significant, with (G+) and without (G-) manure application

Başak sayısı incelendiğinde; ana parsel uygulamaları açısından en yüksek başak sayısı, tüylü fiğ, geleneksel nadas, geç nadas, anız+sap ilavesi ve yaygın fiğ ile aynı istatistiki grupta yer alan 178.2 adet $/ \mathrm{m}^{2}$ ile yazlık mercimek uygulaması sonrasından elde edilmiştir. Bununla birlikte gübreli ve gübresiz uygulamalar (alt parsel) açısından başak sayıları arasındaki fark istatistiki olarak önemli bulunmuş ve gübreli uygulamalardan daha yüksek değer edilmiştir. Ana parsel $x$ alt parsel interaksiyonu ise istatistiki olarak önemsiz bulunmuştur. Bitki boyu ve tane verimi bakımından incelendiğinde; gübreli ve gübresiz koşulların yer aldığı alt parsel uygulamalarında ortalamalar arasındaki fark istatistiki olarak önemli $(p<0.01)$ bulunmuştur. Her iki özellik yönünden de gübreli uygulamalardan elde edilen değerler "a" istatistiki grubunda yer almıştır. Yeşil gübre bitkileri ve nadas uygulamaları yönünden makarnalık buğdayda elde edilen en yüksek tane verimi; tüylü fiğ, geleneksel nadas, geç nadas ve yaygın fiğ ile aynı istatistiki grupta yer alan yazlık mercimekten (241.7 kg/da) elde edilmiştir (Çizelge 3). 
Çizelge 3. Makarnalık buğdayda metre karedeki başak sayısı, bitki boyu ve tane verimi değerleri

Table 3. Spike numbers per square meter, plant lengths and yields of durum wheat

\begin{tabular}{|c|c|c|c|c|c|c|c|c|c|}
\hline \multirow{4}{*}{$\begin{array}{l}\text { Y. g.bitkileri ve } \\
\text { Nadas uyg }\end{array}$} & \multicolumn{3}{|c|}{ Başak sayısı (adet $\left./ \mathrm{m}^{2}\right)$} & \multicolumn{3}{|c|}{ Bitki boyu $(\mathrm{cm})$} & \multicolumn{3}{|c|}{ Tane verimi (kg/da) } \\
\hline & \multirow{3}{*}{$\begin{array}{l}\text { Ana } \\
\text { Parsel }\end{array}$} & \multirow{2}{*}{\multicolumn{2}{|c|}{$\begin{array}{l}\text { Ana x Alt } \\
\text { Parsel İnt. }\end{array}$}} & \multirow{3}{*}{$\begin{array}{l}\text { Ana } \\
\text { Parsel }\end{array}$} & \multirow{2}{*}{\multicolumn{2}{|c|}{$\begin{array}{l}\text { Ana } \times \text { Alt } \\
\text { Parsel Int. }\end{array}$}} & \multirow{3}{*}{$\begin{array}{l}\text { Ana } \\
\text { Parsel }\end{array}$} & \multirow{2}{*}{\multicolumn{2}{|c|}{$\begin{array}{l}\text { Ana } \times \text { Alt } \\
\text { Parsel Int }\end{array}$}} \\
\hline & & & & & & & & & \\
\hline & & $\mathrm{G}+$ & G- & & G+ & G- & & & G- \\
\hline Tüylü fiğ (TF) & 151.7abc & 163.5 & 140.0 & 63.1 & 66.3 & 60.0 & $233.7 a b$ & 258.4 & 209.1 \\
\hline Tritikale $(\mathrm{T})$ & $112.2 d$ & 136.5 & 88.0 & 60.6 & 64.0 & 57.3 & $159.0 \mathrm{e}$ & 184.4 & 133.5 \\
\hline Aspir & $138.6 \mathrm{~cd}$ & 141.6 & 135.6 & 62.4 & 63.5 & 61.3 & $197.9 \mathrm{~cd}$ & 210.4 & 185.4 \\
\hline Geleneksel nadas & 157.2abc & 169.1 & 145.2 & 63.0 & 64.7 & 61.3 & $224.8 \mathrm{abc}$ & 236.7 & 212.8 \\
\hline Geç nadas & 170.3ab & 186.1 & 154.5 & 64.4 & 67.0 & 61.8 & $221.6 a-d$ & 241.9 & 201.3 \\
\hline Anıtsap ilavesi & $152.7 \mathrm{abc}$ & 161.4 & 144.0 & 63.6 & 67.1 & 60.0 & $195.9 d$ & 218.2 & 173.6 \\
\hline TF+T karışımı & $139.5 \mathrm{~cd}$ & 143.5 & 135.4 & 61.6 & 62.7 & 60.5 & $208.3 \mathrm{bcd}$ & 226.5 & 190.1 \\
\hline Kışlık mercimek & $145.6 \mathrm{bc}$ & 149.6 & 141.5 & 62.8 & 66.1 & 59.6 & $194.9 d$ & 214.0 & 175.9 \\
\hline Yazlık mercimek & $178.2 \mathrm{a}$ & 170.9 & 185.4 & 64.8 & 66.4 & 63.2 & $241.7 a$ & 255.8 & 227.6 \\
\hline Yaygın fiğ & 159.2abc & 164.6 & 153.8 & 61.7 & 63.8 & 59.5 & 228.7ab & 244.4 & 213.0 \\
\hline Ortalama & 150.5 & $158.7 \mathrm{~A}$ & $142.3 \mathrm{~B}$ & 62.8 & $65.2 \mathrm{~A}$ & $60.4 \mathrm{~B}$ & 210.7 & $229.1 \mathrm{~A}$ & $192.2 \mathrm{~B}$ \\
\hline $\mathrm{F}_{\text {(alt parsel) }}$ & ** & & & ** & & & ** & & \\
\hline $\mathrm{F}_{(\text {ana parsel) }}$ & ** & & & öd. & & & ** & & \\
\hline$F_{(\text {alt } x \text { ana parsel int.) }}$ & öd. & & & öd. & & & öd. & & \\
\hline $\mathrm{AÖF} \mathrm{F}_{(0.05) \text { (alt parsel) }}$ & 8.68 & & & 1.25 & & & 10.22 & & \\
\hline $\mathrm{AÖF}_{(0.05)(\text { ana parsel) }}$ & 28.05 & & & - & & & 27.81 & & \\
\hline AÖF ${ }_{(0.05) \text { (alt } x \text { ana } p \text { int) }}$ & - & & & - & & & - & & \\
\hline $\mathrm{DK}_{(\%)}$ & 10.70 & & & 3.69 & & & 9.01 & & \\
\hline
\end{tabular}

F: *) 0.05 düzeyinde önemli, $\left.{ }^{* *}\right) 0.01$ düzeyinde önemli, öd.) önemli değil, gübre uygulaması G+:var, G-:yok

$F^{*}$ significant at 0.05 level, ${ }^{* *}$ significant at 0.01 level, öd.) non significant, with (G+) and without (G-) manure application

Makarnalık Buğdayda İncelenen Kalite Özellikleri

Farklı yeşil gübre bitkileri ve nadas uygulamaları sonucunda, makarnalık buğdayda elde edilen hektolitre ağırlı̆̆ı, bin tane ağırlığı ve SDS sedimantasyon değerleri Çizelge 4'te, b sarılık renk değeri, irmik verimi ve protein oranı ise Çizelge 5'de verilmiştir.

Ana parsel ortalama değerleri yönünden, uygulamalar arası farklııı hektolitre ağırlığı, bin tane ağırlığı, b sarılık renk değeri ve protein oranı parametrelerinde istatistiki olarak önemli bulunmuştur. Alt parsel ortalama değerleri yönünden, irmik verimi hariç incelenen kalite parametrelerinin hepsinde uygulamalar arasındaki fark istatistiki olarak önemli çıkarken, ana parsel $x$ alt parsel interaksiyonu yönünden ise incelenen kalite özelliklerin hiçbirinde farklılık önemli bulunmamıştır (Çizelge 4, 5).

Hektolitre ağırlığı, buğdayın kalitesini belirlemede kullanılan en yaygın ve en basit ölçülerden biridir. Hektolitre ağırlığına tanenin dolgunluğu, yoğunluğu, şekli, büyüklüğü ve homojenliği ile içerdiği yabancı madde miktarı etki etmektedir (Ünal 2002). En yüksek hektollitre ağırlığı tritikale, geç nadas, anız+sap ilavesi ve yaygın fiğ uygulamaları ile aynı istatistiki grupta yer alan aspir $(76.7 \mathrm{~kg} / \mathrm{hl})$ yeşil gübre uygulamasından elde edilmiştir.
Talgre et al. (2009) tarafından yapılan bir çalışmada, kırmızı üçgül sonrası ekilen buğdayda hektolitre ağırlığı olumlu yönde etkilenmiştir. Fiziksel kalite analizlerden olan bin tane ağırlığı ise, buğdayın bin tanesinin gram cinsinden ağırlığı olup, çeşit, iklim ve toprak koşullarından etkilenmektedir. En yüksek bin tane ağırlığı değerleri ise, aspir ve geç nadas uygulamaları ile aynı istatistiki grupta bulunan geleneksel nadas ve sap+anız ilavesi uygulamalarında $(36.2 \mathrm{~g})$ saptanmıştır. Her iki kalite parametresi için, gübre uygulamasından elde edilen değerler daha yüksek çıkmış ve "a" istatistiki grubunda yer almıştır. Wivstad et al. (1996) tarafından yapılan çalışmada, yeşil gübrelemenin yazlık buğdayda hektolitre ağırlığı artırdığı, bin tane ağırlığını ise etkilemediği belirlenmiştir. SDS sedimentasyon analizinde gübre uygulamaları arasındaki fark, istatistiki olarak önemli çıkmış $(p<0.01)$, gübre uygulanması ile daha yüksek ortalama değer (29.9 ml) elde edilmiştir. Azotlu gübre uygulamasıyla, buğdayda protein miktarı artmakta, dolayısıyla da protein miktar ve kalitesinin göstergesi olan SDS sedimentasyon değerinde de bir atış söz konusu olmaktadır (Çizelge 4).

Makarnalık buğday kalite değerlendirmesinde en önemli kalite parametrelerinden biri olan $b$ sarılık değeri, daha çok genetik kontrol altındadır. 22.67-23.33 arasında değişim gösteren b sarılık 
Çizelge 4. Makarnalık buğdayda hektolitre ağırlığı, bin tane ağırlığı ve SDS sedimantasyon değerleri Table 4. Hectoliter weight, thousand kernel weight and SDS sedimentation values of durum wheat

\begin{tabular}{|c|c|c|c|c|c|c|c|c|c|}
\hline \multirow{3}{*}{$\begin{array}{l}\text { Yeşil gübre bitkileri ve } \\
\text { Nadas uygulamaları }\end{array}$} & \multicolumn{3}{|c|}{$\begin{array}{c}\text { Hektolitre ağırlığı } \\
(\mathrm{kg} / \mathrm{hl})\end{array}$} & \multicolumn{3}{|c|}{$\begin{array}{c}\text { Bin tane ağırlığı } \\
(\mathrm{g})\end{array}$} & \multicolumn{3}{|c|}{$\begin{array}{c}\text { SDS Sedimantasyon } \\
(\mathrm{ml})\end{array}$} \\
\hline & \multirow[t]{2}{*}{$\begin{array}{c}\text { Ana } \\
\text { Parsel }\end{array}$} & \multicolumn{2}{|c|}{$\begin{array}{c}\text { Ana x Alt } \\
\text { Parsel İnt, }\end{array}$} & \multirow[t]{2}{*}{$\begin{array}{c}\text { Ana } \\
\text { Parsel }\end{array}$} & \multicolumn{2}{|c|}{$\begin{array}{c}\text { Ana x Alt } \\
\text { Parsel İnt, }\end{array}$} & \multirow[t]{2}{*}{$\begin{array}{c}\text { Ana } \\
\text { Parsel }\end{array}$} & \multicolumn{2}{|c|}{$\begin{array}{c}\text { Ana x Alt } \\
\text { Parsel İnt, }\end{array}$} \\
\hline & & $\mathrm{G}+$ & G- & & $\mathrm{G}+$ & G- & & $\mathrm{G}+$ & G- \\
\hline Tüylü fiğ & $75.4 \mathrm{de}$ & 75.7 & 75.1 & $33.9 d$ & 34.1 & 33.8 & 29.7 & 30.2 & 29.2 \\
\hline Tritikale & 76.3abc & 76.6 & 76.0 & $34.7 \mathrm{~cd}$ & 34.7 & 34.6 & 29.1 & 29.8 & 28.3 \\
\hline Aspir & $76.7 \mathrm{a}$ & 77.4 & 75.9 & $36.0 a b$ & 36.7 & 35.2 & 29.2 & 31.5 & 26.8 \\
\hline Geleneksel nadas & $75.8 \mathrm{~b}-\mathrm{e}$ & 76.5 & 75.1 & $36.2 a$ & 36.2 & 36.1 & 29.5 & 29.8 & 29.2 \\
\hline Geç nadas & $76.1 \mathrm{a}-\mathrm{d}$ & 76.5 & 75.7 & $35.6 a b c$ & 36.9 & 34.3 & 28.6 & 30.3 & 26.8 \\
\hline Anız+sap ilavesi & $76.4 a b$ & 76.7 & 76.1 & $36.2 \mathrm{a}$ & 36.4 & 36.0 & 28.3 & 28.7 & 27.8 \\
\hline Tüylü fiğ+tritikale & $75.2 \mathrm{e}$ & 75.4 & 75.0 & $34.0 \mathrm{~d}$ & 34.3 & 33.7 & 29.7 & 30.0 & 29.3 \\
\hline Kışlık mercimek & $75.8 \mathrm{~b}-\mathrm{e}$ & 75.8 & 75.8 & $34.6 \mathrm{~cd}$ & 34.0 & 35.1 & 29.4 & 29.3 & 29.5 \\
\hline Yazlık mercimek & $75.6 \mathrm{cde}$ & 76.1 & 75.0 & $34.9 \mathrm{bcd}$ & 35.0 & 34.8 & 29.7 & 29.3 & 30.0 \\
\hline Yaygın fiğ & 75.9a-e & 76.5 & 75.3 & $34.7 \mathrm{~cd}$ & 35.2 & 34.2 & 29.9 & 30.2 & 29.7 \\
\hline Ortalama & 75.9 & $76.3 \mathrm{~A}$ & $75.5 \mathrm{~B}$ & 35.1 & $35.3 \mathrm{~A}$ & $34.8 \mathrm{~B}$ & 29.3 & $29.9 \mathrm{~A}$ & $28.7 \mathrm{~B}$ \\
\hline $\mathrm{F}_{(\text {alt parsel) }}$ & ** & & & * & & & $* *$ & & \\
\hline $\mathrm{F}_{(\text {(ana parsel) }}$ & * & & & ** & & & öd. & & \\
\hline $\mathrm{F}_{(\text {(alt } x \text { ana parsel int, })}$ & öd. & & & öd. & & & öd. & & \\
\hline AÖF $(0.05)$ (alt parsel) & 0.25 & & & 0.51 & & & 0.78 & & \\
\hline $\mathrm{AÖF}_{(0.05)(\text { ana parsel) }}$ & 0.80 & & & 1.20 & & & & & \\
\hline $\mathrm{AÖF}_{(0.05)(\text { alt } x \text { ana parsel int,) }}$ & - & & & - & & & & & \\
\hline $\mathrm{DK}_{(\%)}$ & 0.61 & & & 2.71 & & & 4.93 & & \\
\hline
\end{tabular}

Çizelge 5. Makarnalık buğdayda b sarılık renk değeri, irmik verimi ve protein oranı değerleri

Table 5. Color b (yellow) value, semolina yield and protein ratio of durum wheat

\begin{tabular}{|c|c|c|c|c|c|c|c|c|c|}
\hline \multirow{3}{*}{$\begin{array}{l}\text { Yeşil gübre bitkileri ve } \\
\text { Nadas uygulamaları }\end{array}$} & \multicolumn{3}{|c|}{$\begin{array}{c}\text { Hektolitre ağırlığı } \\
(\mathrm{kg} / \mathrm{hl})\end{array}$} & \multicolumn{3}{|c|}{$\begin{array}{l}\text { Bin tane ağırlığı } \\
(\mathrm{g})\end{array}$} & \multicolumn{3}{|c|}{$\begin{array}{c}\text { SDS Sedimantasyon } \\
(\mathrm{ml})\end{array}$} \\
\hline & \multirow[t]{2}{*}{$\begin{array}{c}\text { Ana } \\
\text { Parsel }\end{array}$} & \multicolumn{2}{|c|}{$\begin{array}{l}\text { Ana x Alt } \\
\text { Parsel İnt, }\end{array}$} & \multirow[t]{2}{*}{$\begin{array}{c}\text { Ana } \\
\text { Parsel }\end{array}$} & \multicolumn{2}{|c|}{$\begin{array}{l}\text { Ana x Alt } \\
\text { Parsel İnt, }\end{array}$} & \multirow[t]{2}{*}{$\begin{array}{c}\text { Ana } \\
\text { Parsel }\end{array}$} & \multicolumn{2}{|c|}{$\begin{array}{c}\text { Ana x Alt } \\
\text { Parsel İnt, }\end{array}$} \\
\hline & & $\mathrm{G}+$ & G- & & $\mathrm{G}+$ & G- & & $\mathrm{G}+$ & G- \\
\hline Tüylü fiğ & 75.4de & 75.7 & 75.1 & $33.9 d$ & 34.1 & 33.8 & 29.7 & 30.2 & 29.2 \\
\hline Tritikale & $76.3 a b c$ & 76.6 & 76.0 & $34.7 \mathrm{~cd}$ & 34.7 & 34.6 & 29.1 & 29.8 & 28.3 \\
\hline Aspir & $76.7 a$ & 77.4 & 75.9 & $36.0 a b$ & 36.7 & 35.2 & 29.2 & 31.5 & 26.8 \\
\hline Geleneksel nadas & $75.8 b-e$ & 76.5 & 75.1 & $36.2 a$ & 36.2 & 36.1 & 29.5 & 29.8 & 29.2 \\
\hline Geç nadas & $76.1 \mathrm{a}-\mathrm{d}$ & 76.5 & 75.7 & $35.6 a b c$ & 36.9 & 34.3 & 28.6 & 30.3 & 26.8 \\
\hline Anız+sap ilavesi & $76.4 a b$ & 76.7 & 76.1 & $36.2 a$ & 36.4 & 36.0 & 28.3 & 28.7 & 27.8 \\
\hline Tüylü fiğ+tritikale & $75.2 \mathrm{e}$ & 75.4 & 75.0 & $34.0 d$ & 34.3 & 33.7 & 29.7 & 30.0 & 29.3 \\
\hline Kışlık mercimek & $75.8 b-e$ & 75.8 & 75.8 & $34.6 \mathrm{~cd}$ & 34.0 & 35.1 & 29.4 & 29.3 & 29.5 \\
\hline Yazlık mercimek & 75.6 cde & 76.1 & 75.0 & $34.9 \mathrm{bcd}$ & 35.0 & 34.8 & 29.7 & 29.3 & 30.0 \\
\hline Yaygın fiğ & 75.9a-e & 76.5 & 75.3 & $34.7 \mathrm{~cd}$ & 35.2 & 34.2 & 29.9 & 30.2 & 29.7 \\
\hline Ortalama & 75.9 & $76.3 \mathrm{~A}$ & $75.5 \mathrm{~B}$ & 35.1 & $35.3 \mathrm{~A}$ & $34.8 \mathrm{~B}$ & 29.3 & $29.9 \mathrm{~A}$ & $28.7 \mathrm{~B}$ \\
\hline $\mathrm{F}_{\text {(alt parsel) }}$ & $* *$ & & & * & & & $* *$ & & \\
\hline $\mathrm{F}_{(\text {ana parsel) }}$ & * & & & ** & & & öd. & & \\
\hline $\mathrm{F}_{(\text {alt } x \text { ana parsel int, })}$ & öd. & & & öd. & & & öd. & & \\
\hline $\mathrm{AÖF}_{(0.05) \text { (alt parsel) }}$ & 0.25 & & & 0.51 & & & 0.78 & & \\
\hline $\mathrm{AÖF}_{(0.05)(\text { ana parsel) }}$ & 0.80 & & & 1.20 & & & & & \\
\hline $\mathrm{AÖF}_{(0.05) \text { (alt } \mathrm{x} \text { ana parsel int,) }}$ & - & & & - & & & & & \\
\hline $\mathrm{DK}_{(\%)}$ & 0.61 & & & 2.71 & & & 4.93 & & \\
\hline
\end{tabular}

değerinde, tritikale ve anız+sap ilavesi uygulaması dışındaki tüm uygulamalar "a" istatistiki grubunda yer almıştır. Ayrıca gübreli ve gübresiz koşulların yer aldığı alt parsel uygulamalarında, ortalamalar arasındaki fark istatistiki olarak önemli $(p<0.01)$ bulunmuş, gübreli uygulamalardan elde edilen ortalama $b$ sarılık değeri (23.13), "a" istatistiki grubunda yer almıştır. İrmik verimi bakımından hem yeşil gübre bitkileri ve nadas hem de gübre uygulamaları 
arasındaki fark istatistiki olarak önemli olmamıştır. Buğdayın bir amaca uygunluğunu tayin etmede kullanılan en önemli özelliği onun protein miktarıdır. Buğdayların protein miktarları kısmen tür ve çeşide fakat daha çok da yetiştiği yerin toprak ve çevre faktörlerine bağlı olarak \%6-20 arasında değişim gösterir (Özkaya ve Özkaya 2005). Tane protein oranı incelendiğinde, yeşil gübre bitkileri ve nadas uygulamaları arasındaki fark istatistiki olarak önemli $(p<0.0)$ çıkmış, en yüksek protein oranı tüylü fiğ, anız+sap ilavesi, tüylü fiğ+tritikale karışımı ve yazlık mercimek ile aynı istatistiki grupta yer alan geleneksel nadas uygulamasından elde edilmiştir. En düşük protein oranı ise aspir (\%13.3) uygulaması sonrası elde edilmiştir. Talgre et al. (2009) tarafından yapılan çalışmada baklagil yeşil gübresi uygulamasıyla tane proteini \%1.7-3.4 oranında artmıştır. Ayrıca gübre uygulamaları arasındaki fark da istatistiki olarak önemli $(p<0.01)$ bulunmuş, gübre uygulaması "a” grubunda yer almıştır (Çizelge 5).

\section{Sonuç}

Yeşil gübre bitkileri ve nadas uygulamaları iki yılın ortalaması olarak incelendiğinde; özellikle tüylü fiğ sonrası makarnalık buğday ekiminde en iyi sonuçlar alınmış, bu uygulamayı yaygın fiğ ve geleneksel nadas takip etmiştir. En düşük değerler ise tritikale ve kışlık mercimek sonrası ekilen buğdaylardan elde edilmiştir. Gübre uygulamasına göre ise irmik verimi hariç, bütün incelenen özellikler bakımından gübre uygulamasından elde edilen değerler, gübre uygulanmayandan daha yüksek bulunmuştur. Sonuç olarak; Orta Anadolu koşullarında uygun bitki ile uygun amanda yeşil gübre uygulaması yapıldığında, makarnalık buğdayda nadas uygulamasına yakın veya biraz daha yüksek tane verimi alınabildiği ve kalite yönünden de artışın sağlandığı söylenebilir.

\section{Kaynaklar}

Anonim, 1996. Ekolojik Tarım. ETO, İzmir

Anonymous, 1990. AACC Approved Methods. American Association of Cereal Chemist. St. Paul. MN., USA

Anonymous, 1990. MSTAT Users Guide Michigan State University, East Lansing, Chapter 3.1.1., 33-37
Anonymous, 2002a. ICC Standarts. International Association for Cereal Science and Technology, Vienna

Anonymous, 2002b. Standard Practice for Obtaining Spectrophotometric Data for Object-Color Evaluation. American Society for Testing and Materials (ASTM) Method No: E 116

Açıkgöz E., 2001. Yem Bitkileri. Uludağ Üniversitesi, Güçlendirme Vakfı Yayınları, 82, Vipaş A.Ş. Yayınları, 58, Bursa

Atlı A., 1990. Buğday ve Ürünleri Kalitesi. Orta Anadolu'da Hububat Tarımının Sorunları ve Çözüm Yolları Sempozyumu, 8-11 Haziran 1990, Konya, 498-506

Brandt S.A., 1996. Alternatives to summer fallow and subsequent wheat and barley yield on a dark brown soil. Canadian Journal of Plant Science, 76:223-228

Kahnt G., 1983. Grün-düngung. DLG-Verlag, Frankfurt

Karakurt E., 2009. Toprak Verimliliği Yönünden Yeşil Gübreler ve Gübreleme. Tarla Bitkileri Merkez Araştırma Enstitüsü Dergisi, 18 (1-2):48-54

Köksel H., Sivri D., Özboy Ö., Başman A ve Karacan H.D., 2000. Tahıl Laboratuarı El Kitabı. Hacettepe Üniversitesi Mühendislik Fakültesi Yayınları No:47, Ankara

Talgre L., Lauringson E., Roostalu H. and Astover A., 2009. The effects of green manures on yields and yield quality of spring wheat. Agronomy Research, 7(1):125-132

Williams P, Haremein FJ, Nakkoul H, Rihawi S, 1988. Crop Quality Evaluation Methods and Guidelines. ICARDA, Aleppo, Syria

Wivstad M., Salomonsson L. and Salomonsson A.C. 1996. Effects of green manure, organic fertilizers and urea on yield and grain quality of spring wheat. Acta Agric. Scand., Sect. B, Soil and Plant Sci., 46: 169-177

Zabunoğlu S. ve Karaçal İ., 1986. Gübreler ve Gübreleme. Ankara Üni. Ziraat Fak. Yay., 993, Ankara 